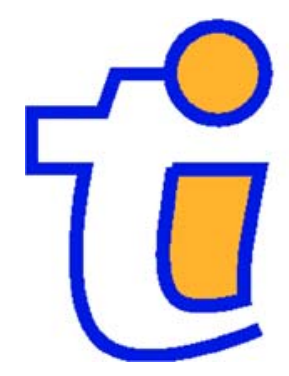

TI 2007-042/3

Tinbergen Institute Discussion Paper

Differential Impact of Environmental Policy Instruments on Technological Change:

A Review of the Empirical Literature

Herman R.J. Vollebergh 


\section{Tinbergen Institute}

The Tinbergen Institute is the institute for economic research of the Erasmus Universiteit Rotterdam, Universiteit van Amsterdam, and Vrije Universiteit Amsterdam.

Tinbergen Institute Amsterdam

Roetersstraat 31

1018 WB Amsterdam

The Netherlands

Tel.: $\quad+31(0) 205513500$

Fax: $\quad+31(0) 205513555$

Tinbergen Institute Rotterdam

Burg. Oudlaan 50

3062 PA Rotterdam

The Netherlands

Tel.: $\quad+31(0) 104088900$

Fax: $\quad+31(0) 104089031$

Most TI discussion papers can be downloaded at http:/ /www.tinbergen.nl. 


\title{
Differential Impact of
}

\section{Environmental Policy Instruments}

\author{
on Technological Change:
}

\section{A Review of the Empirical Literature*}

\author{
Herman R.J. Vollebergh ${ }^{\dagger}$
}

May 15th, 2007

\begin{abstract}
This survey reviews the empirical literature on the impact of environmental policy instruments on the rate and direction of technological change. The survey is explicitly focused on the empirical identification of the hypothesis to expect a stronger impact from market-based incentives than from non-market alternatives. The general picture emerging from the recent literature is that there is a clear impact of environmental policy on invention, innovation and diffusion of technologies. Although studies on a differential impact are still very scarce, the available evidence suggests that innovators look carefully for rent opportunities, which in turn depend on the specific incentives signalled by the type of (environmental) policy.
\end{abstract}

* This research has been supported by the OECD. I would like to thank Nils-Axel Braathen, Nick Johnstone, Arik Levinson, David Popp and participants of the OECD Joint Meeting of Tax and Environment Experts for comments and suggestions on an earlier version of the paper.

${ }^{\dagger}$ Erasmus University Rotterdam and Tinbergen Institute; Email: vollebergh@few.eur.nl

Keywords: Environmental policy instruments, technological change, innovation

JEL Codes: Q38; Q55; Q58

(C) OECD, 2007.

Applications for permission to reproduce or translate all or part of this material should be addressed to: Head of Publications Service, OECD, 2 rue André Pascal, 75775 Paris Cedex 16, France. 


\section{INTRODUCTION}

Stylized facts on decoupling, i.e. the delinking of economic or income growth and environmental pollutants, can be observed in several fields of environmental policy (Brock and Taylor, 2005). For instance, acid rain emissions, particularly emissions of $\mathrm{SO}_{2}$, have been greatly reduced in OECD countries. One reason for these remarkable reductions is the instalment of new (abatement) technologies, such as flue gas desulphurization (FGD) equipment, particularly in those sectors that are most responsible for these emissions. This FGD technology became available in an area of increasing concerns about the likely impact of acid rain emissions and their contribution to local (and distant) air quality. Such concerns gave rise to intensified environmental stringency directed at reducing specific pollutants, such as $\mathrm{SO}_{2}$ emissions.

The idea that environmental policy is of critical importance to the inducement and diffusion of new technologies ('technological change' for short) is hardly disputed nowadays. Economists long ago pointed at what they called the potential dynamic effects of environmental policy. Kneese and Schulze (1975) even claimed that one of the most important criteria on which to judge the performance of environmental policy instruments is the extent to which they spur new technology toward the efficient conservation of the environment. Accordingly, one would expect environmental stringency through emissions restrictions, other than by output reduction or factor substitution, to also be a fundamental driver of an increase in research and development (R\&D) investment in abatement technologies, subsequent filings of new patents and, finally, a reduction in emissions. A relatively recent and new literature is precisely concerned with demonstrating these effects empirically.

Economists also believe that changes in incentives in the background are indispensable. In particular, environmental policy, whether through emissions restriction legislation, changes in (specific) taxes, subsidies or even tradable permits (TDP), is often considered to be an important prerequisite for firms and households to develop and adopt new equipment or technologies with more environmentally favourable characteristics. If incentives matter, one would also expect different policy instruments to have different effects on the rate and direction of technological change. Indeed, economists generally believe that so-called market-based instruments can provide stronger incentives than command and control (CAC) regulations to adopt cheaper and better pollution-control technologies. First, CAC policies, such as emissions prescriptions for 
installations, provide no reward for exceeding the requirements set by the regulations. However, under a market-based policy, firms that perform better than is required by such regulations face continuous rewards because their tax payment can be lowered or they could sell excess pollution permits. Moreover, direct regulations constrain the potential 'space' for innovation, reducing incentives to identify those options that are most cost-effective in the long run.

The focus of this survey is whether there is any empirical evidence for the hypothesis that market-based incentives would have a stronger impact on the rate and direction of technological change than non-market alternatives. This focus distinguishes this survey clearly from some other surveys. For instance, Requate (2005) presents a very useful summary of recent developments in the theoretical literature on this topic. The surveys by Jaffe, Newell and Stavins (2003 and 2005) and Loeschl (2003) mainly focus on the role of technological change in theoretical models, in particular on modelling endogenous technological change, and its likely implications for the environment. Popp (2005) produces some interesting lessons from his and other people's recent empirical work on innovation as measured by patents. However, his focus is not explicitly on the role of instruments, nor does he pay attention to other channels and indicators of the impact of environmental policy on technological change. This survey complements and updates the assessment of Jaffe, Newell and Stavins (2002) because many relevant studies have become available in recent years. The survey is also explicitly concerned with empirical identification of relevant mechanisms, including studies that focus on changes in abatement cost. Recent work on the effect of instruments on innovation through organizational changes within firms is not considered.

The survey starts with a demarcation of our topic. Proper identification of the effect of different environmental policy instruments is far from obvious. Therefore section 2 explains, first of all, the theoretical prediction underlying the hypothesis of a differential dynamic impact of different instrument designs in environmental policy. Next, the section reviews the channels through which this linkage could be studied empirically and the prerequisites to proper identification of this linkage. Section 3 reviews attempts to measure the impact of environmental policy on technological change through commonly used indicators of invention, innovation and diffusion, such as R\&D expenditures, patents and adoption of new technologies. If environmental policy (instruments) has a dynamic impact, one would expect invention and innovation to be affected first. Indeed, there is a large literature that tries to measure such impacts by looking at 
changes in the level and direction of $R \& D$ and/or its (imperfect) output measure, patents. Furthermore, several authors have studied the diffusion of new technology, including studies of abatement cost over time. Sections 4 and 5 review studies that explore the likely effects of specific instruments on the invention, innovation and diffusion of specific technologies. The studies discussed in section 4 identify this linkage for one specific environmental policy instrument, and the studies that explicitly consider comparisons between instruments are reviewed in section 5. Finally, section 6 sums up the main findings and shortcomings in the current literature and provides suggestions for future research.

\section{DYNAMIC EVALUATION OF ENVIRONMENTAL POLICY INSTRUMENTS}

Economists have long recognized the dynamic impacts of environmental policy (instruments) (e.g. Bohm and Russell, 1985), including the potential differential impact of alternative types of environmental policy instruments (Orr, 1976). Also, the link between technological change and the environment has been on the research agenda of economists for a long time (e.g. Stiglitz, 1974). Only recently, however, have economists started to provide better micro-foundations to these early contributions, in particular by allowing for informational complexities and strategic interactions in the regulatory process as well as in the process of technological change. This section summarizes both developments and then explains the implications of these advances for our field of study, i.e. the empirical identification of different impacts of different environmental policy instruments on the rate and direction of technological change.

\subsection{Differential policy impacts and technological change}

The first relevant development in economics is a shift towards a much more detailed analysis of the regulatory process in terms of information and strategy. In particular, the analysis of the effects of environmental policy design on innovation and diffusion requires a much more explicit analysis of the strategy space of both the regulator and the regulated agent. Ranking of policy instruments now strongly depends on how timing and commitment problems are solved. This literature pays much more attention to the micro-foundation of decisions that characterize innovation and diffusion processes in practice, such as decisions about how much to invest in $\mathrm{R} \& \mathrm{D}$ or when to adopt a new technology, and their impact on (optimal) regulation. When it 
comes to characterizing the differences, let alone ranking them, the picture is much less clear-cut (Requate, 2005).

The other development of interest is the growing attention given to the micro-foundation of technological change, which is concisely labelled as endogeneity of technological change. ${ }^{1}$ The underlying mechanisms responsible for economic growth, in particular innovation and diffusion of new technology, came to the notice of a wider audience of economists mainly because of endogenous growth theory (Romer, 1990; Aghion and Howitt, 1992). One important issue is that agents' willingness to invest time or money in research or learning is fraught with public good aspects, i.e. the problematic appropriation of its social value. Since the seminal paper of Arrow (1962), the standard view is that the investor is often not able to get the full return to his investment because new knowledge, once available, is non-rival and only partially excludable through instruments such as patents. Moreover, diffusion of new knowledge is less likely to be instant and immediate across a heterogeneous population. Add these problems to the standard view that the production of environmental quality is associated with externality and public good aspects as well, and the complex nature of choosing optimal policy rules in this area is clear (see in particular Jaffe, Newell and Stavins, 2005).

These advances in economic theory are now used to study the (differential) impact of environmental policy on technological change. In particular, the much more detailed analysis of the creation and diffusion of new knowledge embodied in technologies has been helpful in guiding empirical researchers. Firms typically have to choose how much to invest in R\&D to facilitate invention, whether to patent the results of this phase (if any) and whether or not to produce the new technology or product and commercialize it, i.e. sell it to other firms or households. Usually, the first two decisions are labelled 'invention' and the third decision ‘innovation'. Such decisions are not necessarily restricted to existing firms or within one firm, but are equally likely for new firms or more than one firm. In fact, many firms originate by solving this particular (sub)set of decisions in entirely new ways. Apart from the creation of new technologies and markets, a look at the process that induces firms or households to buy or adopt

1. Recently, attention has shifted to the link between technological change or innovation on the one hand and (economic) growth on the other hand (see, for instance, Aghion et al., 2005) as well as to the underlying incentives that fuel innovation (Aghion and Tirole, 1994). 
new technologies or products once available at the market is also important. This process is usually labelled diffusion. ${ }^{2}$

Note that the effect of environmental policy on the rate and direction of technological change also concerns household decisions. Basically, household investment decisions, such as buying a new refrigerator, are also adoption decisions of new technology already available at the market, but there is some evidence that such decisions of households are quite different from those of firms, apart from the scale of the investment (DeCanio and Watkins, 1998). So we take it that the diffusion phase typically also includes the penetration of new technologies or products to households. Note that the cumulative economic or environmental impact of new technology or products results from all three of these stages and is collectively labelled as the process of technological change (Jaffe, Newell and Stavins, 2002, p. 43).

Economists strongly agree that different types of regulation matter for the rate and direction of technological change. Why one might expect a differential impact of environmental policy instruments on technological change can now easily be understood using Figure 1. This figure illustrates technological change as an inward shift of the abatement cost curve. The idea behind this shift could be explained as follows. Assume a profit maximizing firm produces output $\mathrm{Q}^{\mathrm{P}}$ in the status quo and faces the introduction of a tax $\mathrm{t}^{*}$ on its emissions to internalize the marginal damage associated with its production (MDC). Then it may avoid paying $\mathrm{Ot}^{*} \mathrm{XQ}^{\mathrm{p}}$ by reducing waste or adopting currently available and relatively inexpensive add-on technologies described by the marginal abatement cost curve $\operatorname{MAC}^{0}(\mathrm{E})$. Equivalent incentives could be expected from CAC regulation that forces the firm to adopt this technology and produce at $\mathrm{Q}^{*}$. With a tax or (yearly) auctioned tradable permits (TDP), the firm still faces additional payments equal to $0 t * S Q *$ To avoid paying for the remaining emissions infinitely, this (or other) firm(s) could also invest in invention or innovation to develop new abatement equipment with lower remaining emissions and therefore lower tax payments. If successful, the production possibility set is shifted outwards (higher emissions abatement for a given input), which induces an inward shift of the abatement cost curve (lower costs per unit of emissions abated). This technology, labelled $\mathrm{MAC}^{1}(\mathrm{E})$, reduces tax payments substantially to $\mathrm{Ot}^{*} \mathrm{YQ}^{1}$. So as long as the costs of the new investment are below the tax savings $\mathrm{Q}^{1} \mathrm{YSQ}^{*}$, it pays the firm to adopt the new technology.

2. Note that this distinction associates learning with diffusion of technology and/or knowledge across agents (firms, households) and R\&D with innovation, i.e. invention and application of new technology and/or knowledge. 
Figure 1. Dynamic incentives from environmental regulation

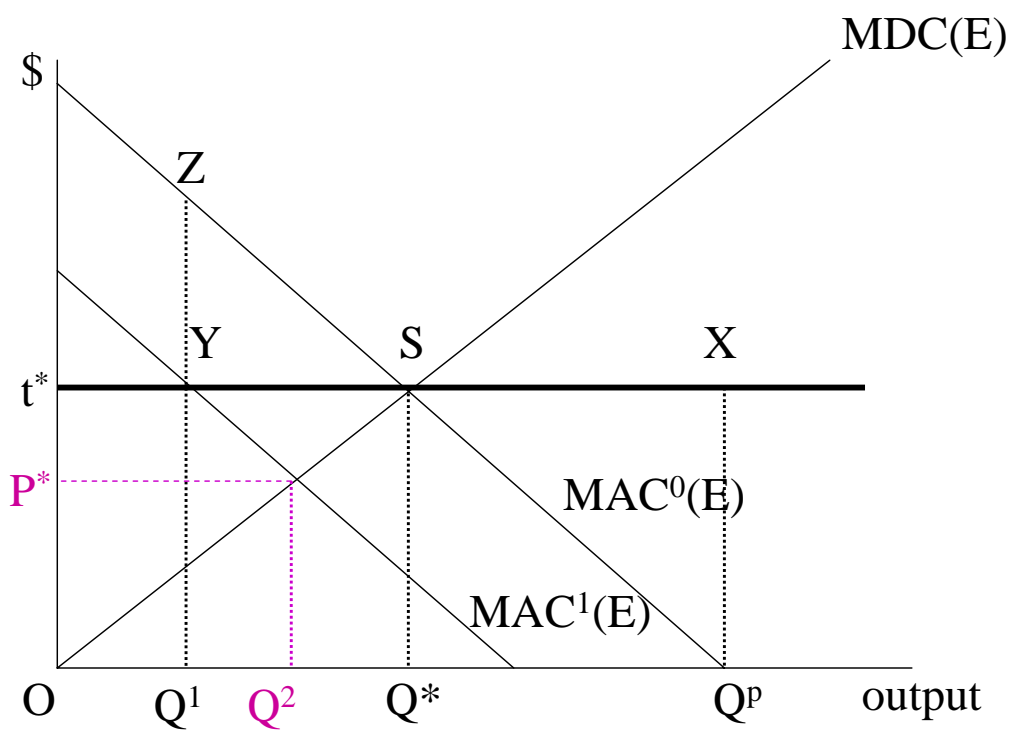

Such incentives for invention and innovation do not exist if a firm does not expect future CAC regulations to be stricter than those currently applied, say at the level of $\mathrm{Q}^{*}$. If the firm complies with these regulations and abatement costs $\operatorname{MAC}^{0}(\mathrm{E})$ are sunk, no additional benefits can be expected from investing in the new abatement equipment labelled $\operatorname{MAC}^{1}(\mathrm{E})$. However, if the firm expects future regulations to be stricter, there remain strong incentives to invest in the development of new technologies. ${ }^{3}$ The firm would save $\mathrm{Q}^{1} \mathrm{ZSQ} \mathrm{Q}^{*}$ from the new technology under this new regulation, which could even be more than savings under a tax scheme.

Note also the remarkable difference between a tax and a TDP system. Whereas the tax t* will remain at its original level unless the government explicitly decides to change it, the tradable permit price will automatically be lower in equilibrium (given by $\mathrm{P}^{*}$ ) because of the induced shift of the MAC curve. As a result, pollution will be higher $\left(Q^{2}>Q^{1}\right)$. The new abatement options reduce the shadow price of pollution, which is reflected in the new permit price and pollution

3. Firms might also anticipate that investment in new (cost-efficient) technologies could be observed by the regulator, who in turn could respond by tougher regulation. Such expectations clearly make innovation and diffusion more costly. 
level, and could also be seen as a rebound effect of the new invention. So much depends upon the timing and commitment of the regulatory policy, which also basically explains why the literature no longer conveys the simple message explained in the previous paragraph. It should be noted, however, that the original conjecture that additional dynamic incentives apply to taxes and (yearly) auctioned permits is still valid ceteris paribus, i.e. in a static framework with an equivalent regulatory outcome.

\subsection{Identification issues}

Only a small empirical literature studies the differential impact of instruments on technological change. This is hardly surprising. First of all, environmental regulation mainly uses CAC instruments, and the use of market-based instruments is (still) rather limited (Stavins, 2003). Second, the same environmental issue is often tackled with a mix or cocktail of instruments, i.e. different instruments, such as (technology) standards, taxes and subsidies, at the same time. From an econometric perspective, nothing, in principle, prevents identification of the effect of different instruments in these circumstances. However, such evaluations require many detailed (micro-)data which are often not available. Third, the alternative approach of comparing the use of instruments in more or less similar circumstances is also rarely used in practice. Although such so-called field experiments also produce reliable effect estimates (Train, 1994), concerns about unequal treatment of agents often prevent this kind of experiment in practice. Fourth, studies that compare instruments in environments where economic conditions are controlled (such as in an experimental setting) are also virtually non-existent.

Despite these problems with measuring the differential impact of instruments directly, an increasing amount of material has become available that documents the impact of environmental policy on technological change. First, some studies have looked at inducement in a more environmentally-friendly direction at a fairly general level in several areas (see also Jaffe, Newell and Stavins, 2002). Furthermore, some evidence is now available for 'stand-alone' evaluation of instruments, which enables comparison of effects across studies. Third, some direct (and indirect) evidence exists as to whether price or quantity regulation makes a difference in a number of cases where market instruments have been applied, in particular in the US.

The overall hypothesis is that (different) instruments are likely to have a (differential) impact on technological change. More specifically, the question is whether market-based 
incentives have a stronger impact on the rate and direction of technological change than nonmarket alternatives. In the early days of environmental regulation, the focus was almost entirely on standard-setting or technology prescriptions (in particular, 'best available techniques'). This encouraged the adoption of so-called add-on technologies, such as scrubbers. When it appeared to the parties involved that these signals would remain and were likely to become even more stringent, firms also started to engage in the development of entirely new (add-on) technologies, sometimes called 'integrated technology'. This process can be observed in many areas, such as water sanitation and purification, air pollution control (smog, acid rain particles, etc.) and waste management. The same holds for technologies that are both directly and indirectly responsible for emissions, such as energy-generating technologies or energy-consuming technologies and products. After an initial phase of retrofitting, usually a search starts for a technology design that tackles concerns about energy and/or emission efficiency from the very beginning.

Against this background, I explain how the overall hypothesis could be tested and what indicators might identify this interaction. First of all, the introduction of environmental policy and its subsequent prolongation signals to (new) producers whether or not it is profitable to engage in $R \& D .{ }^{4}$ If it is, one would expect to observe a rise in R\&D activity specifically dedicated to the invention of new technologies (products) or the improvement of existing ones. Invention of new technologies (products) is usually identified by proxies that:

- measure the (cost of) input to (additional) $R \& D$, such as number of researchers or $R \& D$ 'expenditures';

- measure observable output, such as number of patents and their citations.

Note that spillovers and economies of scale in research complicate the identification of R\&D input specifically dedicated to environmental technology, in particular if we consider integrated technology. Measuring invention of new technologies through patents also has drawbacks. For instance, firms may not always patent to protect their rents or may 'over'-patent as strategic deterrence (Cohen, Nelson and Walsh, 2000; Jaffe and Trajtenberg, 2002). Also, invention of new products is hard to observe directly and is usually only observed through indicators for innovation. Citations of patents account for the relative importance of different patents or can be used to show knowledge flows among inventors.

4. In the current theoretical literature on environmental policy, it is crucial to distinguish between the possible timing and commitment strategies of the regulator and the firm, where each of them can be assumed to move first. 
If it appears that environmental stringency is not a casual exercise, and perhaps even cycles of increasing regulatory stringency might be expected, one is also likely to see more inventions being commercialized. Innovation is an activity that uses inventions as a starting point where R\&D staff is often no longer involved. The outcome is usually implementation of new technologies in the production process or new marketable products. So innovation proxies for new technologies and products are:

- measures of inputs, such as marketing staff using the available stock of patents;

- measures of output, such as entirely new technologies or products, changes in physical characteristics of already existing technologies or products, and changes in the cost per unit of abated emission.

Note that output measures of innovation could typically be observed by looking both at production processes of firms using new technologies and at typical products sold to consumers, because innovation is typically a marketed invention that could be sold either to firms (new technologies) or to consumers (new products).

Finally, environmental regulation is also likely to play a role when it comes to the diffusion of these innovations. Diffusion of a new technology or product reflects the ultimate impact of a particular invention and its subsequent innovation. In particular, the size of the market for a new technology or product is likely to depend on the number of regulated firms. If, for instance, the government provides a tax credit for specific investments, one is likely to observe a faster and stronger penetration of those investments. Proxies to measure this impact are:

- measures of scale, such as number of firms or households that typically use this new technology or product, but also exit of firms that do not innovate;

- measures of cost improvements, such as change in (overall) abatement costs.

Note also that market exit is an indicator of innovation. ${ }^{5}$ One would not expect the firms leaving a regulated market to be a random selection, but typically to be those firms that have substantial problems in adapting to the new (regulatory) environment. This process might be difficult to observe, however, because new regulatory regimes are typically phased in gradually, applying first to new 'entrants' and then to incumbent firms if they switch to new vintages (Levinson, 1999). Abatement cost changes are another indicator of the adoption of new technology. Lower

5. One might call this the 'inverted' Porter hypothesis. According to the Porter hypothesis (Porter and van der Linde, 1995), (certain) innovative firms could gain from regulation and, in addition, could even have a positive effect on overall economic growth. 
abatement cost for a given emissions reduction activity is likely to reflect the arrival of either new technologies ('innovation') or cost savings from the use of a given technology on a wider scale ('diffusion' or 'learning'). As economists typically expect abatement cost to rise for a given emissions-output production possibility set, reductions in abatement cost are often seen as an indicator of dynamic effects.

\section{ENVIRONMENTAL POLICY AND INDUCED TECHNOLOGICAL CHANGE}

This section reviews the empirical literature on the impact of environmental policy on technological change at a general level. The papers that focus on this linkage are summarized in Table 1. From the theory, we know that innovation and diffusion respond to changes in relative prices (Aghion and Howitt, 1992; Acemoglu, 2002). Hence, changes in the rate and direction of technological change can also be induced by purposive changes in relative prices, for instance by a regulator who introduces emissions taxes. Note also that CAC regulation has such an impact because this raises the (implicit) price of emissions (e.g. Copeland and Taylor, 2003; Fullerton, 2002). Technology choice (including investment in invention) is also likely to be affected by indirect mechanisms that have a beneficial effect on the environment. For instance, a rise in the energy price would shift technological change towards less energy-intensive technologies, the use of which, in turn, also reduces emissions as long as energy and emissions are complements.

Popp (2002) is perhaps the most important recent study that confirms the role of prices in inducing technological change to date. This paper contains clear econometric evidence that the filing of US patents is sensitive to changes in relative prices, in particular between 1970 and 1994 . Specifically, Popp shows that rising fossil fuel prices, in particular oil and gas prices, raise the cost of this type of energy use (and its associated emissions) and induce patents (and citations) for energy-saving technologies. Technology groups such as fuel cells, use of waste as fuel or for heat production, and coal gasification have clearly benefited from the changes in energy prices over time. Furthermore, the paper demonstrates the importance of the usefulness of the (endogenous) existing knowledge stock. Popp constructs productivity estimates to measure this usefulness. Not taking this quality of the knowledge stock into account is likely to create omitted variable bias when estimating the effect of energy prices on patents.

To identify the link between environmental regulation and technological change, one would like to look at the consequences of (changes in) the stringency of regulation for existing 
firms or sectors as measured by its implied (changes in) shadow prices. For instance, if regulation is currently not binding, the shadow price for specific elements of the environment (or emissions) as an input is zero and no effects are to be expected. If (expected) regulation becomes binding, the (expected) price becomes positive and firms start to exploit several mechanisms to reduce emissions or the cost of abatement, such as output reduction, substitution of inputs or direct abatement (see Smulders and Vollebergh, 2001). Future (expected) costs can be reduced by investing in ('environmental') R\&D that, if successful, is likely to reduce future abatement costs.

The available empirical papers, however, follow a somewhat different path. Because shadow prices are usually unavailable, stringency is measured through proxies. The most often used proxy is the measure of pollution abatement cost (PAC). This indicator has the advantage that it captures cost consequences of different types of regulation at the firm or sector level, and therefore aggregates implications across different policy dimensions. A set of studies in the late 1990s used PAC to demonstrate an association between higher abatement cost and the propensity to invest in productive $R \& D$ and its likely output, filed patents for environmental technologies. Lanjouw and Mody (1996) were the first to show that this association can be measured across the world. Using patent data at the country level between 1971 and 1988, they explored the number and distribution of environmentally related patents and their diffusion across the world. They found a substantial rate of concentration of such patents, in particular in Germany, Japan and the US. Environmental regulation as measured through PAC as a percentage of GDP also correlates with the share of environmental patents in the total number of patents for these countries. Lanjouw and Mody also observed that innovators in developing countries obtained a non-trivial number of patents and that substantial imports of foreign patents occurred.

Jaffe and Palmer (1997) explored the association between environmental policy and technological change at the industry level for the US. Using patents as well as measures of R\&D between 1974 and 1991, they found that there is a significant correlation within industries over time between the rate of (lagged) expenditure on pollution abatement and the level of $R \& D$ spending, although the magnitude of this effect is small. Furthermore, no such correlation could be observed with overall patenting. In contrast to the latter finding, Brunnermeier and Cohen (2003) reported a positive correlation when also including the number of inspections as a measure for the intensity of regulation. In their study of the US manufacturing sector between 1982 and 
1992, patents respond to increases in PAC but not to increased enforcement. They also found that industries that are internationally competitive are more likely to innovate.

Two papers of particular interest are Becker and Henderson (2000) and Greenstone (2002). These papers focus on the role of entry and exit of firms in response to environmental regulation, which is an indicator of Schumpeterian dynamics. Both papers use attainment status of US counties as a proxy for differences in environmental regulation. ${ }^{6}$ Becker and Henderson (2000) examine unintended effects of air quality regulation using US plant data for 1967-92. They use the differential in regulatory stringency as revealed by the annual designation of county air quality attainment status, which has been applied since 1978. The regulator uses this tool as an incentive mechanism, with greater regulatory oversight - including specific equipment requirements - on plants in non-attainment areas and more favourable regulation in attainment areas. As a consequence, plant births are reduced in non-attainment areas by 26-45\%, with bigger (polluting) industries and sectors being affected the most. The industrial structure also shifts toward less regulated single-plant firms in these areas, whereas large pre-regulation plants benefit from grandfathered provisions, but at the expense of environmental degradation.

Similar evidence is reported by Greenstone (2002), who looks at these effects at an even more detailed level. Not only does his study operationalize environmental stringency through a simultaneous evaluation of all air regulation, but he also studies effects on employment, capital stock and shipments for existing and newly opened plants. He also reports a substantial decline in manufacturing activity in non-attainment counties, although it has been modest compared with that in the entire manufacturing sector. Accordingly, both papers nicely document the decline of polluting industries.

These findings seem to provide little support for the idea that environmental regulation might trigger 'win-win' situations at an aggregated level (Porter and van der Linde, 1995). However, this might still hide potential 'win-win' effects within the polluting industry if the cleaner firms have gained relative to the polluting firms within that industry (ceteris paribus the overall decline of that industry). The likely existence of a first 'win' has been demonstrated by Snyder, Miller and Stavins (2003) when studying the effect of environmental regulation (dummies) on the adoption of membrane cell technology and the exit of firms within US chlorine

6. Attainment status also captures - at least implicitly - what is called 'new source bias' of regulations, i.e. the fact that the phase-in of new regulation is often a gradual process, with new plants or firms facing the strictest regulations (compare also Levinson (1999) and a recent paper by Bushnell and Wolfram (2006)). 
manufacturing plants over the period 1976-2001. They report that regulation increases the price of chlorine and leads to the exit of facilities using environmentally inferior options. Interestingly, adoption of this technology was not found to be directly affected by this regulation. In other words, without switching to the more beneficial technology, firms have a larger chance of exiting the industry. Whether this has left the remaining firms to actually gain from this regulation (the second win) is still unclear, however.

Economists typically also ask whether environmental regulation has a detrimental effect on aggregate productivity, for instance because of crowding-out effects on R\&D (Smulders and De Nooij, 2003). When a given dollar of investment is spent on (research in) pollution reduction, other potentially more productivity-enhancing options are no longer possible. To assess whether such crowding-out effects are present at the sectoral level, Shadbegian and Gray (2005) study abatement cost in sectors where they are relatively large, in particular in paper mills, oil refineries and steel mills. Pollution abatement costs are defined as capital expenditures and operating cost, including labour, materials and depreciation, to reduce emissions to air, water or ground (including waste reduction). ${ }^{7}$ Their measure of productivity distinguishes explicitly between traditional output and 'environmental output' to account for what they call the 'mismeasurement effect', i.e. productivity measures that do not differentiate between these different goals of input use. Using a micro-dataset for plants in the three sectors, they find that abatement expenditures contribute little or nothing to production but also have no statistically significant effects on the productivity of non-abatement expenditures. Further decompositions to allow for heterogeneity in production technologies within these sectors provide little evidence for differences across these groups.

7. PACs in most industrial sectors are well below $1.0 \%$ of total production costs, but they are much higher for the sectors studied by Shadbegian and Gray. 


\section{Table 1. Empirical studies of the effect of environmental policy on technological change}

\begin{tabular}{|c|c|c|c|c|}
\hline Authors & Main focus & Policy driver and indicator & Dataset & Main result \\
\hline Popp (2002) & Innovation & $\begin{array}{l}\text { Energy price on patents of energy } \\
\text { supply and demand technologies and } \\
\text { citations }\end{array}$ & $\begin{array}{l}\text { US energy patent data } 1970- \\
94 \text { and productivity estimates } \\
\text { using citations }\end{array}$ & $\begin{array}{l}\text { Energy prices and quality of existing (stock of) knowledge } \\
\text { strongly affect innovation }\end{array}$ \\
\hline $\begin{array}{l}\text { Lanjouw and } \\
\text { Mody (1996) }\end{array}$ & Innovation & $\begin{array}{l}\text { Environmental regulation (PAC) on } \\
\text { share of environmental / total number } \\
\text { of patents }\end{array}$ & Country data 1971-88 & $\begin{array}{l}\text { Share between } 0.6 \% \text { and } 3 \% \text { in Germany, Japan and US; } \\
\text { patents correlate with PAC for these countries; imports of } \\
\text { foreign patents substantial in developing countries }\end{array}$ \\
\hline $\begin{array}{l}\text { Jaffe and } \\
\text { Palmer (1997) }\end{array}$ & $\begin{array}{l}\text { Invention and } \\
\text { innovation }\end{array}$ & $\begin{array}{l}\text { Environmental regulation (PAC) on } \\
\text { R\&D expenditure and patents }\end{array}$ & $\begin{array}{l}\text { US manufacturing sector } \\
\text { panel data 1974-91 }\end{array}$ & $\begin{array}{l}\text { Lagged PAC has a positive effect on R\&D expenditure but } \\
\text { little effect on patents }\end{array}$ \\
\hline $\begin{array}{l}\text { Brunnermeier } \\
\text { and Cohen } \\
\text { (2003) }\end{array}$ & Innovation & $\begin{array}{l}\text { Environmental regulation (PACE and } \\
\text { inspections) on patents }\end{array}$ & $\begin{array}{l}146 \text { US manufacturing sector } \\
\text { panel data 1982-92 }\end{array}$ & $\begin{array}{l}\text { Patents respond to increase in PAC but not to increased } \\
\text { enforcement; internationally competitive industries more } \\
\text { likely to innovate }\end{array}$ \\
\hline $\begin{array}{l}\text { Becker and } \\
\text { Henderson } \\
\text { (2000) }\end{array}$ & Diffusion & $\begin{array}{l}\text { Environmental regulation (CAA - } \\
\text { attainment or not) on plant births }\end{array}$ & $\begin{array}{l}\text { Large dataset on plants in four } \\
\text { manufacturing sectors } 1967- \\
92\end{array}$ & $\begin{array}{l}\text { Differential in county air quality attainment status favours } \\
\text { attainment areas, reducing births for polluting industries in } \\
\text { non-attainment areas; large pre-regulation plants benefit } \\
\text { from grandfathering }\end{array}$ \\
\hline $\begin{array}{l}\text { Greenstone } \\
(2002)\end{array}$ & Diffusion & $\begin{array}{l}\text { Environmental regulation (CAA - } \\
\text { attainment or not) on measures of } \\
\text { industrial activity (incl plant births) }\end{array}$ & $\begin{array}{l}\text { US plant data set } 1967-1987 \\
\text { (1.75 mln observations) }\end{array}$ & $\begin{array}{l}\text { CAAAs substantially retarded the growth of polluting } \\
\text { manufacturers in nonattainment counties; decline was } \\
\text { modest compared to size of entire manufacturing sector }\end{array}$ \\
\hline $\begin{array}{l}\text { Snyder, Miller } \\
\text { and Stavins } \\
(2003)\end{array}$ & $\begin{array}{l}\text { Innovation } \\
\text { and diffusion }\end{array}$ & $\begin{array}{l}\text { Environmental regulation (dummies) } \\
\text { on adoption of membrane cell } \\
\text { technology and exit of firms }\end{array}$ & $\begin{array}{l}51 \text { US chlorine manufacturing } \\
\text { plants 1976-2001 }\end{array}$ & $\begin{array}{l}\text { Regulation increases price of chlorine and as a result exit } \\
\text { of facilities using environmentally inferior options; } \\
\text { adoption of technology not directly affected (hazard } \\
\text { model) }\end{array}$ \\
\hline $\begin{array}{l}\text { Shadbegian and } \\
\text { Gray (2005) }\end{array}$ & & $\begin{array}{l}\text { Environmental regulation (PAC) on } \\
\text { productivity }\end{array}$ & $\begin{array}{l}68 \text { US paper mills, } 55 \text { oil } \\
\text { refineries and } 27 \text { steel mills } \\
1979-90\end{array}$ & $\begin{array}{l}\text { Abatement expenditures contribute little or nothing to } \\
\text { production, but also do not affect productivity of non- } \\
\text { abatement }\end{array}$ \\
\hline
\end{tabular}

CAA = Clean Air Act

$\mathrm{PAC}=$ pollution abatement costs

PACE $=$ pollution abatement and control expenditures 
In conclusion, environmental regulation has a serious impact on technological change in general. Regulation makes life more difficult for existing firms by increasing the (implicit) price of pollution, but it also has a clear positive impact on invention and innovation of new technologies. Also, indirect evidence suggests that rising implicit prices of emissions boost patents in complementary areas. The use of pollution abatement cost as a proxy to measure the stringency of environmental policy may also have drawbacks. For example, the way in which PAC is measured does not account for technological change in abatement at all (Iovanna, Maguire and McGartland, 2003), which might help explain why its level appears rather constant (as a percentage of GDP) over time (see Brock and Taylor, 2004). ${ }^{8}$ A final note is that almost all studies deal exclusively with US environmental policy; therefore little is known about peculiarities of circumstances affecting results in other countries.

\section{POLICY INSTRUMENTS AND INDUCED TECHNOLOGICAL CHANGE}

A different approach is to study the effects of specific instruments on invention, innovation or diffusion of specific technologies. The set of studies discussed in this section identify this effect for one specific environmental policy instrument; studies that explicitly consider comparisons between instruments are reviewed in the next section. The papers are ordered in relation to whether CAC or market-based instruments are analysed and are summarized in Table 2. Studies that consider technological change only implicitly are not included. ${ }^{9}$

That environmental policy does affect technological change is basically confirmed in all studies, with perhaps one exception. In particular, Bellas (1998) reports no technological progress from standards on flue gas desulphurization (FGD) units at coal-burning plants. Using changes in present-value FGD expenditures over the lifetime of (old and new) units as the dependent variable, with installation year as a proxy for vintage, he finds only weak evidence for some cost advantages of new units over older ones. At least as important is his finding that the operating costs of an existing unit decrease over time. During his observation period, 1970-91, stringency

8. PACs may provide a measure of external regulatory pressures that induce technological change, but some PACs are notoriously difficult to measure (e.g. the PAC component of a new investment project that makes a plant both cleaner and more productive).

9. Examples are studies measuring the effectiveness of policy instruments without looking explicitly at their implications for either abatement technologies or cost, such as Berkhout, Ferrer-i-Carbonell and Muskens’s (2004) evaluation of the effect of energy taxes on household consumption of energy and Fullerton and Kinnaman's (1996) evaluation of the effect of waste taxes on the level and composition of household waste. 
of regulation of new units is determined, in part, by state-of-the-art pollution abatement technology. So any potential rent for the firm due to cost reduction from installing a new and better unit is subsumed by the regulator (by increasing stringency). An existing unit is likely to be governed by standards that existed when the unit began operation. Because any cost saving from such a unit would be retained by the firm itself, the firm has a strong incentive to improve operation - which is exactly what has been observed.

Popp (2006a) also explicitly considers the effect of a specific type of regulation (i.e. standards for $\mathrm{NO}_{\mathrm{x}}$ and $\mathrm{SO}_{2}$ emissions) on technological change in three countries - the US, Germany and Japan - between 1970 and 2000. As in his other studies, he measures this change through the filing of patents and, in this case, citations as well. As this regulation was explicitly focused on abatement of $\mathrm{NO}_{\mathrm{x}}$ and $\mathrm{SO}_{2}$ emissions, it is interesting to see that patents of air pollution control equipment respond so strongly. Popp reports that inventors respond to environmental regulatory pressure in their own country, but not to foreign environmental regulations. Citations of existing patents show that domestic inventors are building on earlier Japanese technology. The latter finding suggests that technology transfers mainly appear indirectly, and firms adapt foreign inventions to local circumstances.

In another study, Popp (2006b) looks at the interaction between invention and innovation on the one hand, and the diffusion of knowledge through embodied abatement technology by a specific set of regulated firms, i.e. US coal-fired power plants, on the other. The narrow focus on patents and adoption of $\mathrm{NO}_{\mathrm{x}}$ pollution control equipment provides an excellent opportunity to explore the interaction of supply and demand of new (abatement) technology in response to emissions regulation, in this case $\mathrm{NO}_{\mathrm{x}}$ standards in the US. Popp considers the creation of a patent data knowledge stock between 1970 and 2002, and abatement technology adoption of the very same technologies by 996 US coal-fired power plants between 1990 and 2002. He finds that technological advances, in particular abroad, are important for the adoption of newer postcombustion treatment technologies. Again, adaptive R\&D by US firms can be observed before foreign inventions are adopted. He also finds that expectations of future technological advances delay adoption.

Clearly, both studies by Popp confirm the previous finding that CAC policy does affect technological change. The somewhat anomalous finding by Bellas might be due to the different indicator used and the period observed to measure this change. Popp (2005) has argued that 
measuring technological change through variations in the time trend might not be a proper way to measure inducement because it only captures the overall effect of technological change. Technological change in these empirical models is typically measured as a time-related change in (energy or environmental) productivity, having controlled for changes in labour, capital and energy inputs. This does not tell us anything about likely changes in the nature ('direction') of the technologies used. Patent data can be used to measure such changes directly.

Three papers have looked explicitly at the effect of earmarked taxes, i.e. tax-cum-rebate schemes, on innovation or diffusion in three different European countries. ${ }^{10}$ Kemp (1998) shows that diffusion of biological effluent treatment plants in the Dutch food and beverage industry between 1974 and 1991 has been sensitive to the Dutch water effluent charge. In particular, he reports that the timing of the adoption of such plants has been influenced strongly. This result confirms the idea that prospective adopters trade-off the costs of effluent treatment against the savings on effluent tax payments. Kemp also finds that adoption strongly depends on firm-specific characteristics, such as the use of investment selection criteria which cannot be directly controlled by the regulator. Unfortunately, this study does not explicitly control for the CAC regulation that affected these firms at the same time.

The study by Millock and Nauges (2006) evaluates the effect of a tax-cum-rebate scheme in France using observations for 226 plants from three industrial sectors between 1995 and 1998. Under this scheme, $\mathrm{SO}_{2}, \mathrm{NO}_{\mathrm{x}}$ and $\mathrm{HCl}$ emissions are taxed and the revenue is returned to the sector. The authors report that this instrument has contributed to the reduction in emissions of $\mathrm{SO}_{2}, \mathrm{NO}_{\mathrm{x}}$ and $\mathrm{HCl}$, but the abatement elasticity with regard to the tax is quite small.

Höglund Isaksson (2005) studies the effect of the Swedish $\mathrm{NO}_{\mathrm{x}}$ charge implemented in 1992. The revenues from this charge are refunded net of transaction costs and firms receive output-based instead of emissions-based refunds. The drawback of output-based refunding is that diffusion of abatement technology is hampered because firms may strategically prevent information disclosure to other firms. Looking at abatement cost (PAC) changes for 162 energy abatement measures implemented in 114 combustion plants, Höglund Isaksson estimates that extensive emissions reduction has taken place at very low cost. She also finds that learning and

10. Tax-cum-rebate schemes are an example of the two-part instrument found to be an optimal incentive scheme when pollution or emissions are considered as inputs (see Fullerton and Wolverton, 2005). Under such a scheme, the polluter pays a deposit for using the environment as an input and receives a rebate when he abates emissions. Accordingly, only net emissions are taxed under this scheme. 
technological development in abatement are present. Note that the remarkable differences in abatement elasticities between her study and Millock and Nauges (2006) might be explained by the fact that the Swedish charge is 100 times higher than the French $\mathrm{NO}_{\mathrm{x}}$ tax studied in the latter. $^{11}$

Subsidies have always met scepticism among economists (see Baumol and Oates, 1988). Indeed, from recent surveys of the adoption literature (Requate, 2005) and market-based instruments (Stavins, 2003), it is clear that the economics profession has focused predominantly on pollution taxes, tradable pollution permits and quotas. Despite the fact that the subsidy instrument is not popular among economists, it is actually quite often used in practice. Subsidies appear in many forms: not only are explicit investment subsidies widely used, but also tax deductibility schemes are very common - including investment credits, accelerated depreciation, partial expensing, and exemptions (Jenkins and Lamech, 1992; Price et al., 2005; OECD, 2006).

One widely studied subsidy programme has been the Demand Side Management (DSM) programme operated by US electric utilities in the 1990s. Empirical evidence from this programme seems to support the economists' belief that subsidies are ineffective and inefficient. Hassett and Metcalf (1995) show, however, that energy-conservation credits given to households have been effective in stimulating the penetration of modern energy-saving technologies. Using much better (panel) data at the household level than previous studies, their estimated coefficients suggest that subsidies have been effective after all. When including unobservable individual characteristics, such as 'taste' for conservation, they find that US households invested in energysaving technologies, such as insulation and replacing furnace burners. With these proper controls, they find that consumers do respond in a rational way to the energy-conservation incentives of a tax credit. ${ }^{12}$ Hassett and Metcalf (1995, p. 213) reproduce previous results showing no, or even adverse, effects when not controlling for these unobservable characteristics.

11. The French tax is EUR 0.04573 per $\mathrm{kg} \mathrm{NO}_{\mathrm{x}}$ whereas the Swedish charge is EUR 4.4 per $\mathrm{kg}$.

12. Nonetheless, Hassett and Metcalf admit that their result adds little to the knowledge of the deadweight loss attached to this subsidy scheme due to so-called 'free riders', i.e. those agents who in the absence of the subsidy would still have invested in energy-saving technologies. Some studies report that the number of agents whose behaviour is not affected by the subsidy would be high (e.g. Malm, 1996; Wirl and Orasch, 1998; Wirl, 2000). 


\section{Table 2. Empirical studies of impact of specific environmental policy instruments}

\begin{tabular}{|c|c|c|c|c|}
\hline Authors & Main focus & Policy driver and indicator & Dataset & Main result \\
\hline \multicolumn{5}{|c|}{ Command and control instruments } \\
\hline Bellas (1998) & Innovation & $\begin{array}{l}\text { Standards for flue gas } \\
\text { desulphurization (FGD) on design, } \\
\text { performance and abatement cost }\end{array}$ & $\begin{array}{l}144 \text { FGD units in US power } \\
\text { plants } 1970-91\end{array}$ & $\begin{array}{l}\text { No significant technological progress reported (time } \\
\text { trend!), but operating costs decrease over time }\end{array}$ \\
\hline Popp (2006a) & $\begin{array}{l}\text { Invention and } \\
\text { innovation }\end{array}$ & $\begin{array}{l}\mathrm{NO}_{\mathrm{x}} \text { and } \mathrm{SO}_{2} \text { regulation on air } \\
\text { pollution control equipment }\end{array}$ & $\begin{array}{l}\text { Patent and citations data for } \\
\text { US, Germany and Japan } \\
\text { 1970-2000 }\end{array}$ & $\begin{array}{l}\text { Inventors respond to environmental regulatory pressure in } \\
\text { their own country, but not to foreign environmental } \\
\text { regulations; any technology transfer appears indirect }\end{array}$ \\
\hline Popp (2006b) & $\begin{array}{l}\text { Invention, } \\
\text { innovation and } \\
\text { diffusion }\end{array}$ & $\begin{array}{l}\mathrm{NO}_{\mathrm{x}} \text { regulation on patents and } \\
\text { adoption of } \mathrm{NO}_{\mathrm{x}} \text { pollution control } \\
\text { equipment }\end{array}$ & $\begin{array}{l}\text { Patent data knowledge stock } \\
\text { 1970-2002 and } 996 \text { US coal- } \\
\text { fired power plants 1990-2002 }\end{array}$ & $\begin{array}{l}\text { Technological advances, particularly abroad, are important } \\
\text { for adoption of newer post-combustion treatment } \\
\text { technologies; adaptive R\&D by US firms necessary before } \\
\text { foreign innovations adopted }\end{array}$ \\
\hline \multicolumn{5}{|c|}{ Market-based instruments } \\
\hline Kemp (1998) & Diffusion & $\begin{array}{l}\text { Water effluent charge on diffusion } \\
\text { pattern of biological effluent } \\
\text { treatment plants }\end{array}$ & $\begin{array}{l}77 \text { Dutch food and beverage } \\
\text { plants 1974-91 }\end{array}$ & $\begin{array}{l}\text { Water charge stimulated early adoption of biological } \\
\text { effluent treatment plants }\end{array}$ \\
\hline $\begin{array}{l}\text { Millock and } \\
\text { Nauges (2006) }\end{array}$ & Diffusion & $\begin{array}{l}\text { Tax (on } \mathrm{SO}_{2}, \mathrm{NO}_{\mathrm{x}} \text { and } \mathrm{HCl} \text { ) on } \\
\text { emissions with subsidy on emissions } \\
\text { abatement }\end{array}$ & $\begin{array}{l}226 \text { French plants from three } \\
\text { industrial sectors } 1995-98\end{array}$ & $\begin{array}{l}\text { Tax reduces emissions of } \mathrm{SO}_{2}, \mathrm{NO}_{\mathrm{x}} \text { and } \mathrm{HCl} \text {, but } \\
\text { abatement elasticity with regard to the tax is quite small }\end{array}$ \\
\hline $\begin{array}{l}\text { Höglund } \\
\text { Isaksson (2005) }\end{array}$ & Innovation & $\begin{array}{l}\mathrm{NO}_{\mathrm{x}} \text { charge on abatement cost (PAC) } \\
\text { changes }\end{array}$ & $\begin{array}{l}162 \text { energy abatement } \\
\text { measures of } 114 \text { Swedish } \\
\text { combustion plants 1990-96 } \\
\end{array}$ & $\begin{array}{l}\text { Extensive reduction at low cost; learning and technological } \\
\text { development in abatement would be present }\end{array}$ \\
\hline $\begin{array}{l}\text { Hassett and } \\
\text { Metcalf (1995) }\end{array}$ & Diffusion & $\begin{array}{l}\text { Energy tax credit on residential } \\
\text { conservation investment }\end{array}$ & $\begin{array}{l}\text { 37,658 US households 1979- } \\
81\end{array}$ & $\begin{array}{l}\text { Energy tax credits increase probability of investment in } \\
\text { energy-saving technology }\end{array}$ \\
\hline $\begin{array}{l}\text { Aalbers et al. } \\
\text { (2007) }\end{array}$ & Diffusion & $\begin{array}{l}\text { Adoption subsidy on investment in } \\
\text { expensive innovative technology }\end{array}$ & Managers in experiment & $\begin{array}{l}\text { Strong behavioural impact of subsidy in experimental } \\
\text { setting for managers }\end{array}$ \\
\hline $\begin{array}{l}\text { DeCanio and } \\
\text { Watkins (1998) }\end{array}$ & Diffusion & $\begin{array}{l}\text { Voluntary Green Lights programme } \\
\text { on energy-saving investment } \\
\text { decisions by firms }\end{array}$ & $\begin{array}{l}\text { 9,548 US companies with } 268 \\
\text { participants }\end{array}$ & $\begin{array}{l}\text { Firm characteristics matter for participation in and } \\
\text { commitment to programme }\end{array}$ \\
\hline $\begin{array}{l}\text { Klaassen et al. } \\
\text { (2005) }\end{array}$ & $\begin{array}{l}\text { Innovation } \\
\text { and diffusion }\end{array}$ & $\begin{array}{l}\text { R\&D and adoption subsidy on cost- } \\
\text { reducing innovation }\end{array}$ & $\begin{array}{l}\text { Wind turbine farms in } \\
\text { Denmark, Germany and UK }\end{array}$ & $\begin{array}{l}\text { Estimation supports two-factor learning curve ('learning } \\
\text { by doing' and 'learning by searching') and homogeneous } \\
\text { learning curves for the three countries }\end{array}$ \\
\hline
\end{tabular}


In what is perhaps the first experimental study on the behavioural impact of environmental policy instruments, Aalbers et al. (2007) analyse the impact of technology adoption subsidies on investment behaviour in an individual choice experiment in which managers from firms participated. By using an economic experiment, the authors are able to construct the decision environment of agents in such a way that they all essentially face the same investment decision under slightly different circumstances. Moreover, the experimental setting is such that decisionmakers also face binding time constraints, to mimic the decision situations in which managers in small and medium enterprises find themselves. In these smaller firms, there is insufficient managerial time available to search for the best available technology and, at the same time, follow the output market sufficiently closely to maximize profits (see DeCanio, 1998). Aalbers et al. find that subsidies are highly effective as an incentive mechanism even if only a small (expensive) subset of available technologies are subsidized and the subsidy does not make these technologies profitable. The managers realize much higher savings in the treatment with subsidy than in the treatment without subsidy. Furthermore, the subsidies seem to induce more radical choice behaviour: either managers adopt (very) early or they do not purchase a technology at all.

The importance of firm characteristics for the effectiveness of environmental policy in general and the diffusion of new technology in particular has also been nicely demonstrated by DeCanio and Watkins (1998). They report that self-selection of firms participating in the voluntary Green Lights programme of the US Environmental Protection Agency is evident. Even when controlling for firm-specific differences in risk classes, firms tend to differ systematically rather than randomly when participating in the programme. It appears that Green Lights membership is positively associated with good performance by firms and with sectoral and regional characteristics that suggest the importance of informational diffusion.

A final study of interest is the case study by Klaassen et al. (2005) on the support for wind turbines in Germany, Denmark and the UK. As explained in their paper, progress in wind turbine technology and the accumulated experience in producing wind turbines are likely to be affected by initial R\&D subsidies and a gradual shift towards adoption subsidies to increase demand in a later stage. ${ }^{13}$ The findings of Klaassen et al. suggest similar learning curves for the

13. The innovation and diffusion mechanism is studied here using a so-called two-factor learning curve, which is a typical bottom-up perspective on the development and spread of new technologies. According to this concept, cost reductions for particular technologies arise out of two kinds of learning. The first mechanism is called 'searching' and typically arises because of investment in the stock of R\&D (and its lagged effect). The second mechanism is labelled 'learning by doing', but this concept is somewhat more general here, 
different countries. Import indicators for the UK (80\%) and Germany (40\%) reflect a leading role for Denmark, which is hardly surprising because Denmark supported investment in innovation for windmills much earlier than the other countries. Accordingly, this case study provides casual evidence for the Porter hypothesis, although it remains unclear whether environmental policy is beneficial in this case even beyond the environmental dividend itself. Moreover, a case study can never generate a general confirmation of any hypothesis, but it does seem to give some indication that at some specific place and time, environmental policy might be favourable to growth in particular sectors.

The studies reviewed in this section all explicitly deal with specific environmental instruments and their likely effect on invention, innovation or diffusion. They often claim that such effects exist, but their identification is not always convincing. Moreover, the studies are hard to compare. First of all, instruments have specific design features that determine their incentives, which in turn are likely to have an impact on their effectiveness. Second, local circumstances tend to differ and isolation of policy effects is usually very difficult. Third, specific indicators used to measure technological change may differ. The overall impression, though, is that environmental policy instruments, whether they are CAC or market-based, have a clear impact on technological change. To find out more about their differential dynamic impact, we now turn to studies that take this perspective explicitly into account.

\section{DIFFERENTIAL DYNAMIC IMPACT OF POLICY INSTRUMENTS}

This section reviews studies that explicitly analyse the differential impacts from different types of environmental policy instruments on technological change. For a long time, comparisons have only used indirect evidence, because of the lack of market-based instruments in practice and/or the availability of data to evaluate them. In particular, several studies have looked at CAC versus energy price effects. Only recently have some papers become available that compare the effects of CAC instruments versus market-based instruments for some interesting cases. The papers are summarized in Table 3.

because it allows not only for improvements in (on-the-spot) applications of such technologies and their uses, but also for the development of 'new' technology. The typical empirical indicator is cumulative capacity, as it is assumed that this type of learning grows as more of the technology is applied. 
Table 3. Empirical studies of differential impacts of environmental policy instruments

\begin{tabular}{|c|c|c|c|c|}
\hline Authors & Main focus & Policy driver and indicator & Dataset & Main result \\
\hline \multicolumn{5}{|c|}{ Indirect instruments } \\
\hline Greene (1990) & Diffusion & $\begin{array}{l}\text { Gasoline prices vs. CAFE } \\
\text { standards on increasing fuel } \\
\text { economy }\end{array}$ & $\begin{array}{l}15 \text { sets of manufacturer } \\
\text { CAFE data for } 1978-89\end{array}$ & $\begin{array}{l}\text { CAFE standards were a significant constraint for many } \\
\text { manufacturers, and were perhaps twice as influential as } \\
\text { gasoline prices }\end{array}$ \\
\hline $\begin{array}{l}\text { Jaffe and Stavins } \\
\text { (1995) }\end{array}$ & Diffusion & $\begin{array}{l}\text { Energy price vs. building codes } \\
\text { on adoption of thermal insulation } \\
\text { technologies in new residential } \\
\text { construction }\end{array}$ & $\begin{array}{l}\text { US state-level data on } \\
\text { thermal insulation } 1979-88\end{array}$ & $\begin{array}{l}\text { Mean energy efficiency increases with higher energy prices } \\
\text { (adoption decisions are more sensitive to upfront cost than to } \\
\text { longer-term operation expenses) }\end{array}$ \\
\hline $\begin{array}{l}\text { Newell, Jaffe and } \\
\text { Stavins (1999) }\end{array}$ & $\begin{array}{l}\text { Invention and } \\
\text { innovation }\end{array}$ & $\begin{array}{l}\text { Energy price vs. regulation on } \\
\text { new models offered for sale }\end{array}$ & $\begin{array}{l}\text { Energy characteristics of air } \\
\text { conditioners and gas water } \\
\text { heaters 1958-93 }\end{array}$ & $\begin{array}{l}\text { Rate of overall innovation independent of, but direction } \\
\text { responsive to, energy prices and regulations; in particular, } \\
\text { subset of technologically feasible models offered for sale }\end{array}$ \\
\hline \multicolumn{5}{|c|}{ Direct instruments } \\
\hline $\begin{array}{l}\text { Revelt and Train } \\
\text { (1998) }\end{array}$ & Diffusion & $\begin{array}{l}\text { Rebates or loans on high- } \\
\text { efficiency appliances for } \\
\text { households }\end{array}$ & $\begin{array}{l}\text { 6,081 choice experiments of } \\
401 \text { customers in US }\end{array}$ & $\begin{array}{l}\text { Demand Side Management is effective, but loans have larger } \\
\text { impact than rebates (plus more profitable for firm) }\end{array}$ \\
\hline $\begin{array}{l}\text { Kerr and Newell } \\
\text { (2003) }\end{array}$ & Diffusion & $\begin{array}{l}\text { CAC and TDP under US lead } \\
\text { phase-down }\end{array}$ & 378 US refineries 1971-95 & $\begin{array}{l}\text { Increased stringency encouraged greater adoption of new } \\
\text { technology; differential between adoption propensity of } \\
\text { expected permit sellers relative to expected permit buyers } \\
\text { higher under TDP than under CAC }\end{array}$ \\
\hline $\begin{array}{l}\text { Carlson et al. } \\
\text { (2000) }\end{array}$ & Diffusion & $\begin{array}{l}\text { CAAA with CAC and TDP-SO } \\
\text { on marginal abatement costs }\end{array}$ & $\begin{array}{l}734 \text { units of US power } \\
\text { plants 1985-94 }\end{array}$ & $\begin{array}{l}\text { Declining marginal abatement cost for both CAC and TDP } \\
\text { due to fuel switching and technological change (time trend!); } \\
\text { cost savings (relatively) larger under TDP }\end{array}$ \\
\hline $\begin{array}{l}\text { Lange and Bellas } \\
\text { (2005) }\end{array}$ & $\begin{array}{l}\text { Innovation } \\
\text { and diffusion }\end{array}$ & $\begin{array}{l}\text { CAAA with CAC and TDP-SO } \\
\text { on scrubber cost }\end{array}$ & $\begin{array}{l}\text { Comparison of } 157 \text { pre- and } \\
40 \text { post-CAAA boilers in US } \\
\text { power plants } 1985-2002\end{array}$ & $\begin{array}{l}\text { More recent scrubbers cheaper to purchase and operate than } \\
\text { older scrubbers, but cost reductions seem to be one-time drop } \\
\text { rather than continual decline }\end{array}$ \\
\hline Popp (2003) & $\begin{array}{l}\text { Invention and } \\
\text { innovation }\end{array}$ & $\begin{array}{l}\text { CAAA with CAC and TDP-SO } \\
\text { on patents of scrubbers }\end{array}$ & $\begin{array}{l}180 \text { FGD units in US power } \\
\text { plants } 1972-97\end{array}$ & $\begin{array}{l}\text { Little evidence that new patents before } 1990 \text { improved ability } \\
\text { of scrubber technology; patents granted during TDP system of } \\
\text { 1990s improved removal efficiency of scrubbers }\end{array}$ \\
\hline
\end{tabular}

CAA = Clean Air Act

CAAA $=$ Clean Air Act Amendments 1990

CAFE $=$ corporate average fuel economy

FGD = flue gas desulphurization

TDP $=$ tradable permits 
The first set of studies use variation in energy prices as a proxy for variation in the stringency of market-based instruments and compare their effects with those of CAC instruments. Note that a rise in the energy price is also likely to shift technological change towards less energy-intensive technologies, the use of which, in turn, also reduces emissions as long as energy and emissions are complements. In particular, several studies use hedonic price functions to examine the effects of public policy in the contexts of home appliances and of the energy efficiency of cars. Such cases are used to study the differential impact of instruments on variation in different indicators of technological change.

The interesting study by Newell, Jaffe and Stavins (1999) uses a product-characteristics approach to evaluate the relative impact of energy prices and changes in energy-efficiency standards. This approach captures the important effect of invention creating new 'models' with characteristics not previously feasible and of innovation commercializing models that were not previously offered for sale. ${ }^{14}$ The authors apply their approach to the changing energy characteristics of models of air conditioners and gas water heaters between 1958 and 1993. The evidence suggests that the rate of innovation was independent of energy prices and regulations, whereas its direction is induced for some products. Energy price changes also had a considerable effect on the subset of technically feasible models offered for sale, and this responsiveness increased substantially after product labelling was required. Regulations worked largely through energy-inefficient models being dropped ('exit'), which is in fact the intended effect of energyefficiency standards.

Two other, somewhat older, studies examined indirect effects of changes in implicit emissions prices, such as changing fuel prices. The study of Greene (1990), for instance, looked at the interesting practical experiment provided by standards imposed on the fuel efficiency of cars. Before his study it was reported that the fuel efficiency of new cars in the US responds more than proportionally to changes in (expected) fuel prices (as explained by Jaffe, Newell and Stavins, 2002, pp. 60-61). Greene, however, showed that the CAFE standards introduced by the US government also had an effect, in particular for US automobile manufacturing firms. He estimated that the CAFE constraint was binding for US-based firms but not for foreign (European and Japanese) firms. Specifically, CAFE standards had perhaps twice as much influence as gasoline

14. According to this approach, induced innovation is the movement in the frontier of feasible models that reduce the cost of energy efficiency in terms of other attributes (see Newell et al. (1999), pp. 943ff). 
prices. Accordingly, the experiment in the car market suggests that the responsiveness of technological change to prices is significant, but also that binding standards could be exploited as an important vehicle for technological change.

The study by Jaffe and Stavins (1995) also looked at the relative importance of CAC versus market-based instruments for the diffusion of new technology. In particular, they evaluated the role that (changes in) energy prices and building codes had on adoption of thermal insulation technologies in new residential construction in the US between 1979 and 1988. They found that the mean energy efficiency increases with higher energy prices and rising adoption cost. Using an economic model to explain the relative magnitudes, their estimates suggest that ad valorem energy taxes in the 10-25\% range have noticeable impacts on the energy efficiency of new homes, and that this impact would be felt rather quickly. Adoption subsidies of similar magnitude would have an even larger impact because adoption decisions were found to be more sensitive to upfront cost than to longer-term operation expenses (Jaffe and Stavins, 1995, p. 59). As far as direct regulation is concerned, they also did not find any discernible effects on building practices. This might provide some evidence that if (new) standards are set below existing standards, they will have no effect on the margin, whereas energy taxes (and subsidies) always do.

Further evidence that reducing upfront cost (or postponing cost) does have considerable impact on adoption decisions is provided by the paper of Revelt and Train (1998). They studied the relative importance of rebates or loans for the adoption of high-efficiency appliances by households in the US. The typical subsidy employed under the Demand Side Management (DSM) approach by the US electric utilities is a rebate to induce households to adopt these appliances. To study the potential effect of loans, Revelt and Train used stated-preference data to estimate the effect of loans relative to the effect of rebates. Using 6,081 choice experiments of 401 customers, they concluded that DSM is effective but that loans have larger impact than rebates. This is surprising because if upfront costs were the basic problem, the individual would prefer the rebate over a loan (of equivalent money). As explained by Revelt and Train (1998, p. 652), however, individuals may not be indifferent and they may see the subsidy as a signal. It is clear for a loan that the lender makes money from it, but a rebate is a 'giveaway' and customers may wonder what its motivation is. If individuals start wondering about its motivation, their behaviour is likely to be affected. For instance, if an individual is suspicious about the benefactor, he or she might not buy the appliance, just for that reason. 
Finally, at least four recent studies have analysed CAC instruments against the use of tradable permits. I start with a recent study by Kerr and Newell (2003) on the relative effectiveness of CAC and tradable permits in the US lead phase-down in the 1980s. This was the first case where TDP were applied in practice, in particular in controlling the lead in leaded gasoline between 1983 and 1987. Kerr and Newell employed a unique panel on 378 US petroleum refineries between 1971 and 1995 to study adoption decisions by refineries of lead-reducing technology under different regulatory regimes. ${ }^{15}$ Diffusion is considerably different under the two regulatory regimes. In particular, the positive differential in the adoption propensity of expected permit sellers (i.e. low-cost refineries) relative to expected permit buyers (i.e. high-cost refineries) was greater under the market-based regime than under individually-binding, but non-tradable, performance standards.

The remaining three studies all focus on the differential dynamic impact of TDP and CAC in the case of the US Clean Air Act Amendments (CAAA), which have allowed emissions trading since 1990. These case studies clarify why identification of such impacts is difficult and therefore provide further evidence of the importance of proper comparison between policy regimes applied in practice. First of all, Carlson et al. (2000) make clear why simple correlations between the introduction of an instrument, such as allowance trading in the case of CAAA, and abatement cost reductions should be treated with care. As they explain in detail, some officials suggest that the introduction of allowance trading of $\mathrm{SO}_{2}$ was the main reason for the strong decline in abatement cost of $\mathrm{SO}_{2}$ as measured by the permit price. Indeed, ex-ante estimates of marginal abatement costs produced at the time that the CAAA were written were as high as $\$ 1,500$, whereas the allowance price, which is an ex-post signal of marginal abatement costs, was only around \$100 in 1997. Instead of making inferences about the causality of the introduction of the allowance scheme, one might equally well see this as evidence that the (ex-ante) estimate was simply wrong. Similarly, it would be false to attribute this effect to the trading mechanism per se as well as to dynamic effects that would have been caused by this scheme.

Carlson et al. (2000) aim to distinguish carefully between reduction in abatement cost due to trading on the one hand and other reasons, such as fuel substitution or the instalment of

15. Kerr and Newell's (2003) evaluation is based on a theoretical model of technology adoption. According to this model, firms adopt gradually if costs fall and increased stringency increases the value of adoption. Firms with lower benefits or higher costs will adopt more slowly. Divergence in adoption propensity between low- and high-compliance-cost plants is also expected under different regulatory regimes, in particular under a TDP system and an individually-binding performance standard. 
new technology, on the other hand. They estimate marginal $\mathrm{SO}_{2}$ abatement costs for 734 units of US power plants between 1985 and 1994. Their estimates suggest that the decline in marginal abatement costs could be attributed to technical improvements (as measured through the time effect), including advances in the ability to burn low-sulphur coal at existing generators, as well as to improvements in overall generating efficiency, but mostly to a decline in fuel costs. Further estimations to identify the potential gains from trade under the TDP regime suggest that under both CAC (phase I) and the allowance regime (phase II) marginal abatement costs have fallen. ${ }^{16}$ Finally, this study provides estimates of potential cost savings of trade and show that they are (and will be) considerable for the TDP regime.

The paper by Lange and Bellas (2005) focuses on the effects of the policy differential on advancement in scrubber technology only. As discussed earlier, Bellas (1998) found little evidence for cost advances of new technologies as employed by power plants in the pre-CAAA period from 1970 to 1991. Bellas only found learning effects over the use of existing technologies. In their paper, Lange and Bellas estimate the effects of allowance trading on scrubber costs using a hedonic model. The model does not focus on the reduction in compliance cost, but on the scrubbing costs instead, in order to isolate a potential dynamic (technology) effect. Like the paper by Newell, Jaffe and Stavins (1999), this paper identifies technological change by adjusting cost changes for design and operating parameters. Lange and Bellas find that more recent scrubbers are cheaper to purchase and operate than older scrubbers, but also that these cost reductions are a one-time drop rather than a continual decline.

Popp (2003) also looks at advances in scrubber technology, in particular at the invention stage. He combines the filing of new patents for scrubbing technology with the actual instalment of this technology in 180 FGD units in US power plants between 1972 and 1997 to study the effect of these patents on pollution control. He finds that the level of innovation for FGD units, measured by the number of successful patent applications per year, was actually higher before permits were introduced in 1990. However, the new patents from before 1990 have not improved the removal efficiency of scrubbers. Innovation focused only on reducing operating costs, which is basically in line with the finding by Lange and Bellas (2005) for the same period. ${ }^{17}$ After the

16. Note that, as a consequence, the gains from trade should fall as well (see Carlson et al. (2000), p. 1295).

17. There remains a difference, however, as to whether operating cost did fall prior to the CAAA of 1990 (Popp, 2003) or did not (Bellas, 1998). 
allowance system was introduced, innovation not only lowered scrubber costs but also improved removal efficiency. Accordingly, the change to market-based environmental regulation did not induce more innovation, but led to more environmentally-friendly innovation.

Clearly, the introduction of allowance trading of $\mathrm{SO}_{2}$ for electric utilities in the US has had an impact on the direction of technological change in this area. This impact, however, very much depends on how it is identified. In particular, as also noted by Popp (2005, p. 219), the type of policy affects the nature of innovation, and this nature remains hidden in overall abatement cost estimates with a time trend measuring technological change. These insights illustrate that the effect of environmental policy on technological change may not always be properly identified by looking at abatement cost changes alone. Together, the studies reviewed in this section illustrate how difficult it is to identify dynamic impacts of policy instruments, in particular their differential impact. One serious drawback is again that these studies are all for the US only, and it would be interesting to see whether or not the use of market-based regulation in other countries might be location- or culture-specific.

\section{CONCLUSIONS}

The papers reviewed here clearly observe changes in invention, innovation and diffusion of technologies, although the direct causal link with environmental policy is not always clear in specific cases. The overall conclusion seems justified that environmental policy in general has an impact on at least the direction of technological change. This conclusion holds regardless of the type of instrument applied, i.e. whether CAC or market-based instruments are used. Indeed, in the early days of environmental regulation, the focus was almost entirely on standard-setting through technology prescriptions (e.g. prescriptions of 'best available techniques'). Prescriptions are almost by definition technology-forcing and binding because they impose constraints on emissions and therefore also reduce the number of options in the emissions-output possibility set. The most important effect of this (standard-setting) policy - also corroborated by several of the studies reviewed here - is that it induces exit of the dirtiest firms operating in the market.

Equally impressive are the strong correlations between specific regulations and the $R \& D$ process as measured through patenting behaviour. One telling example is Popp’s (2003) finding that the new regulatory environment in the US after the Clean Air Act (CAA) came into force shifts inventions and innovations to further improvements of existing flue gas desulphurization 
(FGD) models in power plants. This is easy to understand because the CAA allows firms to exploit rents from (emission) permits trading. Apparently, and in line with what economists suggest, innovators look carefully for rent opportunities, which in turn depend on the specific incentives signalled by the design of (environmental) policy. This is also precisely what could be learned from cases providing indirect evidence of price incentives, such as the rise (and decline) in fossil fuel prices (e.g. Newell, Jaffe and Stavins, 1999). Emissions reductions clearly benefit from taking a free ride on higher implicit emissions prices due to rising energy prices, because most fossil fuel use is closely linked to air quality emissions. Changes in energy prices induce invention, innovation and diffusion towards more energy-efficient technologies, the use of which, in turn, has a positive impact on lowering emissions levels as well.

If incentives are so important and technological change is so sensitive to the type of regulation being applied, the old adage of economists that market-based instruments have stronger dynamic impacts deserves some nuancing. The evidence here is somewhat different from what might be expected from the early environmental economics literature on instruments. In particular, the papers suggest that standards imposed under CAC also provide clear signals as to what physical properties of production processes are undesirable (Helfand, 1991), which in turn could be targeted by inventors. Standard-driven technological change is directed by the physical signal given by the standard. For instance, if the standard is in gram emission per unit of time, inventors are likely to focus on any new technology that reduces this particular target. Instead, the greater flexibility provided by TDP systems might also direct both R\&D and innovation efforts towards using the flexibility opportunities of existing or 'known' technology only. An important topic for future empirical research would be to see whether market-based instruments indeed create ‘environmental technology' crowding-out effects, i.e. investments in R\&D and innovation away from entirely new opportunities or 'breakthrough' technologies.

If the design of signals is so important (e.g. Laffont and Tirole, 1996), this issue should also be taken more seriously in future empirical research of the dynamic impact of environmental instruments. First of all, an interesting issue is to study more explicitly the type of signals used to induce agents to change their behaviour. Current empirical assessments have a tendency to be biased towards observable ('hard') information, such as changes in abatement costs, number of patents (citations) and physical characteristics of technologies. Apart from serious identification problems, such as whether abatement cost measures properly account for technological change, 
the studies discussed in this review therefore simply neglect effects of regulation on 'soft' information, such as organizational design and changes in attitudes. ${ }^{18}$

Second, more empirical research on the timing and commitment by the regulator is important. Currently, little or nothing is known about the role of the regulator itself and his interaction with the regulated agents over time. Moreover, the link between different regulators in an international setting and technological change is a very interesting topic. It is quite likely that, for instance, international diffusion of knowledge is also sensitive to international cooperation. While diffusion of knowledge has been studied more generally (e.g. Keller, 2004), little work addresses explicitly the links between environmental policy and speed of diffusion between foreign and domestic knowledge ('international technology transfers').

Third, we now know that the conditions under which specific instruments would be equivalent are quite demanding. For instance, an ad valorem tax is equivalent to a specific tax in terms of economic incidence only if monopoly power is absent or quality differentials of goods do not matter and are not mutable (see, for instance, Keen, 1998). For environmental externalities, however, quality differentials and changes are the heart of the matter. The relevant incidence from a social perspective - is precisely in terms of the effectiveness of the internalization of specific physical externalities. Learning more about the dynamic effects of specific designs of instruments, such as taxes, subsidies, standards or TDP systems, on quality change is therefore crucial. For instance, subsidies are usually targeted to specific technologies (a firm is only eligible for a subsidy if it invests in technology X). The dynamic impact of a subsidy therefore crucially depends on the targeting choice with respect to the technology that is subsidized. In the same way, the effect of a tax may depend on the signal the tax sends by its choice of the tax base: the stronger the linkage to specific emissions, the more directed the search for new technologies is likely to be. Empirical research identifying these types of differences in impact between instruments would be most welcome in the future.

18. There is a growing literature trying to empirically investigate these linkages as well. See, in particular, Labonne and Johnstone (2006) and Rennings et al. (2006). 


\section{REFERENCES}

Aalbers, R.F.T., E.C.M. van der Heijden, J.J.M. Potters, D.P. van Soest and H.R.J. Vollebergh (2007), 'Technology adoption subsidies: an economic experiment with students and managers', Tilburg University, mimeo.

Acemoglu, D. (2001), 'Directed technological change', Review of Economic Studies, 69, 781-809.

Aghion, P. and P. Howitt (1992), Endogenous Growth Theory, Cambridge, MA: MIT Press.

Aghion, P. and J. Tirole (1994), 'The management of innovation', Quarterly Journal of Economics, 109, 1185-1209.

Aghion, P., N. Bloom, R. Blundell, R. Griffith and P. Howitt (2005), 'Competition and innovation: an inverted-U relationship’, Quarterly Journal of Economics, 120, 701-728.

Arrow, K. (1962), 'The economic implications of learning by doing', Review of Economic Studies, 29, 155-173.

Baumol, W.J. and W.E. Oates (1988), The Theory of Environmental Policy, second edition, Cambridge: Cambridge University Press.

Becker, R. and V. Henderson (2000), 'Effects of air quality regulations on polluting industries', Journal of Political Economy, 108, 379-421.

Bellas, A.S. (1998), 'Empirical evidence of advances in scrubber technology’, Resource and Energy Economics, 20, 327-343.

Berkhout, P.H.G., A. Ferrer-i-Carbonell and J. Muskens (2004), 'The ex post impact of an energy tax on household energy demand', Energy Economics, 26, 297-317.

Bohm, P. and C.S. Russell (1985), 'Comparative analysis of alternative policy instruments', in A.V. Kneese and J.L. Sweeney (eds), Handbook of Natural Resource and Energy Economics, vol. I, Amsterdam: North Holland.

Brock, William A. and Scott Taylor (2005), "Economic Growth and the Environment: A Review of Theory and Empirics", in: Philippe. Aghion and Steven Durlauf (eds), Handbook of Economic Growth, Elsevier Amsterdam, 1749-1821

Brunnermeier, S. and M.A. Cohen (2003), 'Determinants of environmental innovation in US manufacturing industries', Journal of Environmental Economics and Management, 45, 278293.

Bushnell, J.B. and C. Wolfram (2006), 'The economic effects of vintage differentiated regulations: the case of New Source Review’, CSEM (California), Working Paper 157.

Carlson, C., D. Burtraw, M. Cropper and K. Palmer (2000), 'Sulfur dioxide control by electric utilities: what are the gains from trade?’, Journal of Political Economy, 108, 1292-1326. 
Cohen, W.M., R.R. Nelson and J.P. Walsh (2000), 'Protecting their intellectual assets: appropriability conditions and why U.S. manufacturing firms patent (or not)’, NBER (Boston), Working Paper 7552.

Copeland, B.R. and M.S. Taylor (2003), Trade and the Environment: Theory and Evidence, Princeton: Princeton University Press.

DeCanio, S.J. (1998), 'The Efficiency Paradox: Bureaucratic and Organizational Barriers to Profitable Energy-Saving Investments’, Energy Policy 26(5), 441-454.

DeCanio, S.J. and W.E. Watkins (1998), 'Investment in energy efficiency: do the characteristics of firms matter?', Review of Economic Studies, 80, 95-107.

Fullerton, D. (2002), 'A framework to compare environmental policies', Southern Economic Journal, 68, 224-248.

Fullerton, D. and T.C. Kinnaman (1996), 'Household responses to pricing garbage by the bag', American Economic Review, 86, 971-984.

Fullerton, D. and A. Wolverton (2005), 'The two-part instrument in a second-best world', Journal of Public Economics, 89, 1961-1975.

Gray, W.B. and R.J. Shadbegian (1998), 'Environmental regulation, investment timing, and technology choice’, Journal of Industrial Economics, 46, 235-256.

Greene, D.L. (1990), 'CAFE or price? An analysis of the effects of federal fuel economy regulations and gasoline price on new car MPG, 1978-89’, Energy Journal, 11(3), 37-57.

Greenstone, M. (2002), 'The impacts of environmental regulations on industrial activity: evidence from the 1970 and 1977 Clean Air Act Amendments and the Census of Manufactures', Journal of Political Economy, 110, 1175-1219.

Hassett, K.A. and G.E. Metcalf (1995), 'Energy tax credits and residential conservation investment: evidence from panel data’, Journal of Public Economics, 57, 201-217.

Helfand, G.E. (1991), 'Standards versus standards: the effects of different pollution restrictions', American Economic Review, 81, 622-634.

Höglund Isaksson, L. (2005), 'Abatement costs in response to the Swedish charge on nitrogen oxide emissions’, Journal of Environmental Economics and Management, 50, 102-120.

Iovanna, R., A. Maguire and K. McGartland (2003), 'The pace of PACE at the Environmental Protection Agency’, NCEE (Washington), Working Paper 03-07.

Jaffe, A. and K. Palmer (1997), 'Environmental regulation and innovation: a panel data study', Review of Economics and Statistics, 79, 610-619. 
Jaffe, A.B. and R.N. Stavins (1995), 'Dynamic incentives of environmental regulations: the effects of alternative policy instruments on technology diffusion', Journal of Environmental Economics and Management, 29, 43-63.

Jaffe, A.B. and M. Trajtenberg (2002), Patents, Citations \& Innovations, Cambridge, MA: MIT Press.

Jaffe, A.B., R. Newell and R.N. Stavins (2002), 'Environmental policy and technological change', Environmental and Resource Economics, 22, 41-69.

Jaffe, A.B., R. Newell and R.N. Stavins (2003), 'Technological change and the environment', in K.-G. Mäler and J. Vincent (eds), Handbook of Environmental Economics, Amsterdam: North-Holland.

Jaffe, A.B., R. Newell and R.N. Stavins (2005), 'A tale of two market failures’, Ecological Economics, 54, 164-174.

Jenkins, G.P. and R. Lamech (1992), 'Fiscal policies to control pollution: international experience’, Bulletin for International Fiscal Documentation, 46, 483-502.

Keen, M. (1998), 'The balance between specific and ad valorem taxation', Fiscal Studies, 19, 137.

Keller, W. (2004), 'International Technology Diffusion', Journal of Economic Literature, 62: 752-782.

Kemp, R. (1998), 'The diffusion of biological waste-water treatment plants in Dutch food and beverage industry’, Environmental and Resource Economics, 12, 113-136.

Kerr, S. and R. Newell (2003), 'Policy-induced technology adoption: evidence from the US lead phasedown’, Journal of Industrial Economics, 51, 317-343.

Klaassen, G., A. Miketa, K. Larsen and T. Sundqvist (2005), 'The impact of R\&D on innovation for wind energy in Denmark, Germany and the United Kingdom’, Ecological Economics, $54,164-174$.

Kneese, A.V. and C.L. Schulze (1975), Pollution, Prices, and Public Policy, Washington DC: Brookings Institution.

Labonne, J. and N. Johnstone (2006), 'Environmental policy and economies of scope in facilitylevel environmental management’, OECD, Paris, mimeo.

Laffont, J.J. and J. Tirole (1996), ‘Pollution permits and environmental innovation’, Journal of Public Economics, 62, 127-140.

Lange, I. and A. Bellas (2005), 'Technological change for sulfur dioxide scrubbers under marketbased regulation’, Land Economics, 81, 546-556. 
Lanjouw, J.O. and A. Mody (1996), 'Innovation and the international diffusion of environmentally responsive technology’, Research Policy, 25, 549-571.

Levinson, A. (1999), 'Grandfather regulations, new source bias, and state air toxics regulations', Ecological Economics, 28, 299-311.

Loeschl, A. (2003), 'Technological change in economic models of environmental policy: a survey’, Ecological Economics, 43, 105-126.

Malm, E. (1996), 'An actions-based estimate of the free-rider fraction in electricity utility DSM programs’, Energy Journal, 17, 41-48.

Millock, K. and C. Nauges (2006), 'Ex post evaluation of an earmarked tax on air pollution', Land Economics, 82, 68-84.

Newell, R.G, A.B. Jaffe and R.N. Stavins (1999), 'The induced innovation hypothesis and energysaving technological change’, Quarterly Journal of Economics, 114, 941-975.

OECD (2006), The Political Economy of Environmentally Related Taxes, Paris.

Orr, L. (1976), 'Incentive for innovation as a basis of an effluent charge strategy', American Economic Review, 56, 441-447.

Popp, D. (2002), 'Induced innovation and energy prices’, American Economic Review, 92, 160180.

Popp, D. (2003), 'Pollution control innovations and the Clean Air Act of 1990', Journal of Policy Analysis and Management, 22, 641-660.

Popp, D. (2005), 'Lessons from patents: using patents to measure technological change in environmental models’, Ecological Economics, 54, 209-226.

Popp, D. (2006a), 'International innovation and diffusion of air pollution control technologies: the effects of $\mathrm{NO}_{\mathrm{x}}$ and $\mathrm{SO}_{2}$ regulation in the US, Japan, and Germany', Journal of Environmental Economics and Management, 51, 46-71.

Popp, D. (2006b), 'Exploring links between innovation and diffusion: adoption of NOx control technologies at U.S. coal-fired power plants’, NBER (Boston), Working Paper 12119.

Porter, M.E. and C. van der Linde (1995), 'Toward a new conception of the environmentcompetitiveness relationship’, Journal of Economic Perspectives, 9, 97-118.

Price, L., C. Galitsky, J. Sinton, E. Worrell and W. Graus (2005), Tax and Fiscal Policies for the Promotion of Industrial Energy Efficiency: A Survey of International Experience, Lawrence Berkeley National Laboratory 58128.

Rennings, K., A. Ziegler, K. Ankele and E. Hoffmann (2006), 'The influence of different characteristics of the EU Environmental Management and Auditing Scheme on technical environmental innovations and economic performance', Ecological Economics, 57, 45-59. 
Requate, T. (2005), 'Dynamic incentives by environmental policy instruments: a survey', Ecological Economics, 54, 175-195.

Revelt, D. and K. Train (1998), 'Mixed logit with repeated choices: households' choices of appliance efficiency level', Review of Economics and Statistics, 80, 647-657.

Romer, P.M. (1990), 'Endogenous technical change’, Journal of Political Economy, 98, S71S102.

Shadbegian, R.J. and W.B. Gray (2005), 'Pollution abatement expenditures and plant-level productivity: a production function approach’, Ecological Economics, 54, 196-208.

Smulders, S. and M. de Nooij (2003), 'The impact of energy conservation on technology and economic growth’, Resources and Energy Economics, 25, 59-79.

Smulders, S. and H.R.J. Vollebergh (2001), 'Green taxes and administrative costs: the case of carbon taxation', in C. Carraro and G. Metcalf (eds), Distributional and Behavioral Effects of Environmental Policy, Chicago: Chicago University Press.

Snyder, L.D., N. Miller and R.N. Stavins (2003), 'The effects of environmental regulation on technology diffusion: the case of chlorine manufacturing', American Economic Review, 93, 431-435.

Stavins, R. (2003), 'Experience with market based environmental policy instruments', in K.G. Mäler and J.R. Vincent (eds), Handbook of Environmental Economics, vol. 1, Amsterdam: Elsevier Science.

Stiglitz, J. (1974), 'Growth with exhaustible natural resources: efficient and optimal growth paths’, Review of Economic Studies, 41, 123-137.

Train, K. (1994), 'Estimation of Net Savings from Energy Conservation Programs,' Energy: The International Journal, 19, 423-441

Wirl, F. (2000), ‘Lessons from utility conservation programs’, Energy Journal, 21, 87-108.

Wirl, F. and W. Orasch (1998), 'Analysis of United States' utility conservation programs', Review of Industrial Organization, 13, 467-486. 